\title{
Cells are Us - combining research and public engagement
}

Frances R. Balkwill $\mathbb{D}^{1,2}$

The COVID-19 pandemic has reminded scientists and clinicians about the importance of public engagement with science. One way to make this routine, and improve engagement skills of staff and students, is to embed an informal science learning centre within a research institute.

Throughout my career I have combined cancer research with public engagement - this has been highly synergistic, putting my research in context and improving my communication skills.

\section{Writing science books for children}

This dual career began in the mid 1980s when I was trying to find a 'cell' book to explain to my children what I did at work. I found only one biology book (The Body Book by Claire Rayner) that briefly mentioned cells, describing them as grey jelly like objects with a hard bit in the middle called the nucleus. I had recently given a cell-themed lecture, cleverly illustrated by graphic designer Mic Rolph, to a young audience. Mic had worked on both science and light entertainment television programmes, and I suggested we collaborate to replace the 'cell' gap in children's non-fiction. After many setbacks, we had a four-book deal with the newly formed Harper Collins (Cells are Us, Cell Wars, Amazing Schemes within your Genes and DNA is Here to Stay). Our partnership eventually led to 13 children's books on cell and molecular biology, which have now been translated into about 10 different languages. The latest series (Enjoy Your Cells) is published by Cold Spring Harbor Laboratory Press (CSHLP), most recently in black and white with colouring pencils. One of the most rewarding projects in collaboration with, and inspired by, immunologist Siamon Gordon - was a not-for-profit book published by CSHLP on HIV/AIDs for young people in sub-Saharan Africa. This involved two visits to South Africa; first, for us to find out from young people what they would find most helpful and interesting in such a book, and then to return with the first edition of the book for evaluation by our target audience. From all this experience, I'd advise any aspiring children's science book author to use a narrative. Science has the most amazing stories, and relating these to young people's experiences will add a lot. And don't be afraid to use proper scientific terms - young people love saying 'macrophage' or 'deoxyribonucleic acid'.

\section{Centre of the Cell}

Thirteen years after Cells are Us was first published, I moved my research group to Barts Cancer Institute, Queen Mary University of London, to pursue an interest in translational cancer research. Queen Mary has an impressive history of public engagement, dating back to its origins as the People's Palace in 1887, and it was not long before I was talking with like-minded colleagues about public engagement in biomedicine. When the avantgarde architect Will Alsop was appointed to design what became the Blizard Institute at our East London Whitechapel campus, Mike Curtis, who became its first Director, had the brilliant idea to include a public engagement space, and so Centre of the Cell was born ${ }^{1}$.

After six years of fundraising, front end evaluation, website development and design, our informal science learning centre opened in 2009, the first to be based in a biomedical research building. The innovative design of the Blizard with its vast subterranean laboratory floor means that Centre of the Cell's 'STEM Pod' is suspended above scientists at work. On their journey to STEM Pod, visitors can look down on researchers in action (jokingly referred to by some as 'a scientist zoo'). The immersive Pod experience, a five-scene theatrical mixture of film, digital interactive games and objects on loan from our Barts Pathology Museum, was an award-winning success from the start.

After 12 years and more than 207,000 participants, much has changed. We soon found our visitors wanted to stay longer and learn more. Guided by this, Centre of the Cell has expanded its offerings, adding more and varied activities. We now have fifteen original presenter-led science shows and workshops (for example Snot, Sick and Scabs, Gut Feeling and Microbe Detectives), all linked to the curriculum and delivered on site or via outreach to schools and communities. To accommodate the increasing demand for shows and workshops, in 2019 we opened a second Will Alsop-designed learning space, Neuron Pod, with external multi-coloured dendrites that light up the Whitechapel streets each evening. 
From ages 4 to 19 there is something for each stage of a young person's science journey.

Being embedded within a university, we have a unique and almost infinite resource of cutting-edge science content on which to base our activities. Many activities are funded by components of research grants, and some even contribute to the recruitment of participants to research studies, such as Genes and Health and Children's Health in London and Luton (CHILL).

In response to audience demand, we started a Youth Member Scheme (YMS) that offers work experience and volunteering, careers advice and workshops, study and revision support, an intensive summer school, opportunities to participate in developing new activities or designing research projects, and a science book club. Much of this has temporarily, but successfully, moved online in response to the COVID-19 pandemic.

\section{A blueprint for other research institutes?}

Does Centre of the Cell provide a 'blueprint' for other research institutes? In many respects our operation resembles a research laboratory. Instead of postdocs and technicians, we have explainer staff who present the shows and workshops, learning staff who develop new activities, outreach and operations staff, all with training and experience equivalent to lab personnel. We are dependent on core support from the university (for which we are forever grateful) as well as competitively awarded grant income from trusts, foundations and research-funding bodies. We also rely on income from our visitors, although each visit is heavily subsidised.

While obtaining sufficient funding is often challenging, the benefits to the university, its staff and students are substantial. An informal science learning centre within a research institute engenders a climate of enthusiasm for public engagement with research, and improves the science communication and public engagement skills of staff and students. For instance, one of our funded schemes allows us to employ medical and dental students as assistant explainers. This is a virtuous circle; students support their studies with part time work, developing new skills and confidence, while acting as role models for visitors. Postgraduate students can volunteer as Centre of the Cell Ambassadors, and we provide public engagement training for undergraduates. We also aid recruitment to public health research initiatives ${ }^{2}$ and, with the STEM Teens project, are involved in science learning research with other UK and USA sites ${ }^{3}$.

What are the benefits for our audiences? The importance of informal science learning to overall science capital is well-recognized but allowing visitors to see scientists at work (with appropriate safety and security measures) adds an extra inspirational dimension. Centre of the Cell is surrounded by areas of socioeconomic disadvantage; over half of our YMS members will be the first in their family to go to university. Science learning centres such as Centre of the Cell are well positioned to improve life and career chances for young people, especially those from disadvantaged backgrounds or with low science capital, and support their progression into further study and lifelong engagement with science.

More than fifteen years have passed since we began planning Centre of the Cell. From all this experience I would offer the following advice to anyone considering a similar initiative: decide on the learning aims and 'top-level' message of the entire project and the individual activities; define your target audiences; conduct extensive front end evaluation to understand the knowledge, needs and expectations of these audiences; the most efficient use of your scientists is for them to collaborate with the explainer and learning staff who have the time and experience to translate the science stories into activities that will be relevant to the target audiences; evaluate frequently; and if you are working with school-age children, make sure that there are good curriculum links. But always try and exceed the expectations of your visitors - and remember to include a sense of fun, humour and 'wow' them.

\section{The Future}

Over the next several years, informal science learning will become increasingly valuable as schools focus on catch-up learning and re-inspiring students in practical science. The pandemic has given us is a once-in-a-century science story to tell, and who better to do this than Centre of the Cell and other similar initiatives? More research is needed in the coming years into best practice in public engagement. Studies like STEM Teens are beginning to bridge the gap, but there is still a major challenge in measuring the long-term impact of public engagement and informal science learning. And I believe there will still be a place for science books. As I look back over more than 30 years of science communication, involving the hundreds of collaborators from multiple disciplines I have had the privilege to work with, I feel positive about the influence we have had on the more than 500,000 children who read the books or interacted with Centre of the Cell, excited about our future plans and always grateful for the insights and focus that I have gained from the young people I have worked with.

1. Balkwill, F. \& Chambers, K. Centre of the Cell: Science comes to life. PLoS Biol. 13, e1002240 (2015).

2. Whitehouse, A. L. et al. Airway dendritic cell maturation in children exposed to air pollution. PLOS ONE 15, e0232040 (2020).

3. Mulvey, K. L. et al. Interest and learning in informal science learning sites: differences in experiences with different types of educators. PLOS ONE 15, e0236279 (2020).

Acknowledgements

I am very grateful to all our supporters but would especially like to thank the following current and past funders: Queen Mary University of London; Wellcome Trust; The Medical College of Saint Bartholomew's Hospital Trust; The Drapers' Charitable Fund; Barts Charity; Aldgate and Allhallows Foundation; Clore Duffield Foundation; The National Lottery Heritage Fund; The Mercers' Charitable Foundation; The Hobson Charity: Garfield Weston Foundation; and many other individuals, trusts and foundations who have made Centre of the Cell a continuing success.

Competing interests

The author declares no competing interests. 